\title{
Pengembangan Kluster Industri Militer India dari Sudut Pandang Developmental State Theory
}

\section{Ismiyatun}

Program Studi Hubungan Internasional, Fakultas IImu Sosial dan Politik Universitas Wahid Hasyim Semarang

Sampangan, Jawa Tengah 50232, Indonesia

ismyunwahas@gmail.com

Diserahkan: 24 Agustus 2016, Diterima: 28 Desember 2016

\begin{abstract}
This research was held to investigate India government policy in military industry development by using the instrument of high technology cluster for anticipating revolution on the military affairs. The novelty was lied on its description about Developmental State Theory (DST), especially state domain and strategy toward market. India had half intervention characteristic. State owned enterprises was defended beside took collaboration with the market. The strategy prefers the empowerment of competence qualification for the domestic firm, hold the political agencies networking and diplomacy in order to support the regulation. High technology cluster could reinforce state domain and strategy because of its technology venture which gave power to attain economic diplomacy.

Keywords: Developmental State Theory, State Domain, Military Industry Cluster
\end{abstract}

\begin{abstract}
Abstrak
Penelitian ini bertujuan menginvestigasi kebijakan pemerintah India dalam pengembangan industri militer melalui suatu kluster industri berteknologi informasi, guna mengantisipasi fenomena revolusi dalam militer. Kebaruan penelitian ini terletak pada deskripsinya tentang teori negara developmentalis, khususnya mengenai domain negara dan strategi yang dijalankan terhadap pasar. India memiliki karakteristik setengah intervensi, perusahaan negara tetap dipertahankan disamping tingginya intensitas kolaborasi pasar. Spesifikasi strateginya lebih mengutamakan unsur penguatan melalui standar kompetensi bagi firma domestik, penciptaan jaringan yang mendukung peningkatan agen politik dan diplomasi sebagai pendukung regulasi. Kluster berteknologi tinggi dari sudut teori ini mampu menjadi penguat kelayakan atas tipologi domain negara serta strategi yang dihasilkannya Kata kunci: Teori Negara Developmentalis, Domain Negara, Kluster Industri Militer
\end{abstract}

\section{PENDAHULUAN}

Industri militer India, pasca Perang Dingin, sering dijadikan objek penelitian. Dari sudut pandang keamanan Hoyt (2007) memandang India memiliki tingkat kepedulian cukup tinggi untuk mengembangkan sub sektor ini. Targetnya adalah pemenuhan kebutuhan militer domestik sampai dengan tercapainya kenaikan tingkat kemandirian bangsa dalam hal persenjataan modern. Di sisi lainnya Baskaran (2005) secara khusus meneliti sistem imbal dagang persenjataan mereka. Dari perhitungan ekonomis, disimpulkan bahwa industri militer India dipandang gagal mencapai tingkat kemandirian melalui minimalisasi andil modal asing, sesuai dengan ungkapannya di bawah ini:

"However, India failed to create a defense industry capable of supplying advanced weapon systems that would be competitive with westen equipment. The technology gap hasn't closed".

Artikel ini menelaah kembali hasil dari dua pakar tersebut, namun menggunakan sudut pandang ekonomi politik dengan kerangka konseptual developmental state theory (DST). Aliran developmentalist, mulai bangkit kembali di akhir tahun 1980an sebagai 
reinkarnasi dominasi pemerintah dalam pembangunan guna menjawab tantangan kaum neoliberalist dan globalisasi. Menurut (Weiss, 1998) globalisasi dan peran negara, tidak berkorelasi sebab akibat maupun hubungan yang bersifat zero sum game. Sebaliknya, kedua konsep seimbang, dan tidak saling mengunci, justru menjadi pemicu antara satu dengan lainnya. Negara memiliki kekuasaan, juga kedaulatan, seharusnya mampu mengantisipasi dominasi MNC, keterbukaan ekonomi melalui regulasi domestik dan kerja sama internasional (Weiss, 2000).

Berbagai teori yang terangkum dalam DST merupakan antisipasi yang dilakukan oleh negara berkembang untuk mengantisipasi globalisasi, tuntutan industrialisasi dan pembangunan nasional. Konseptualisasi, teorisasi di dalamnya berkembang lebih lambat apabila dibandingkan aspek praktis. Negara berkembang telah menjalankannya secara langsung melalui kebijakan, meskipun para pembuat kebijakan tidak mempelajari secara langsung DST. Jepang bahkan telah menjalankan kebijakannya melalui konsep flying geese sebelum Johnson maupun Robert Wage menggunakannya sebagai negara model.

Industri militer, ditinjau dari perspektif teori ini tergolong sebagai salah satu sektor industri penyangga, tidak hanya digunakan untuk memenuhi kebutuhan persenjataan nasional, juga harus mampu berfungsi secara ekonomis. Konsekuensinya sektor ini dalam jangka pendek belum mampu berkontribusi dalam peningkatan penghasilan maupun pertumbuhan ekonomi. Kemanfaatan atas pemberdayaannya lebih diutamakan guna peningkatan ketahanan nasional, melalui kelengkapan angkatan bersenjata nasional dengan persenjataan modern bukan dalam kerangka penciptaan lapangan kerja.

Dalam wacana teori ini, industri militer dapat dijadikan sebagai wahana bagi negara berkembang untuk memperoleh kekuasaan struktural dalam bidang teknologi, sehingga pengembangannya melalui suatu kluster teknologi, mutlak dilakukan guna kelangsungannya. Makna kekuasaan struktural disini adalah terciptanya peluang dan pangsa pasar bagi industri militer domestiknya sehingga kelangsungan produksi dan inovasi bisa berjalan seimbang. Mempelajari industri militer dari sudut pandang ini, berarti menelaah kemampuan dari pemerintah sebagai eksekutif di dalam menghadapi jaringan pertahanan internasional, menyelaraskannya dengan kebijakan perdagangan lainnya khususnya di dalam pasar modal maupun investasi asing.

DST sebagai suatu teori tentang tatanan yang dikembangkan negara berkembang sebagai antisipasi terhadap tuntutan penetrasi modal asing dalam pembangunan nasional bisa diekplorasikan guna menjelaskan fenomena pengembangan kluster industri militer di negara berkembang. India sebagai suatu model menurut Mukherji (2016), bukan bersifat klasik. Tatanan serta regulasinya memberikan penguatan dalam kepemilikan saham perusahaan negara namun dalam jangka panjang tidak menutup peluang diinvestasi atas entitas negara ini. Selain itu potensi swasta domestik sebagai agen pembangunan difasilitasi secara seimbang sejalan dengan usaha peningkatan peran modal asing/katalisator.

Dalam kasus India, sub sektor ini menjadi penguat dalih keberadaan DST sebagai tatanan utama perekonomian India secara global, sekaligus menunjukkan data dinamika kebijakan persenjataan India. Kebijakan India dalam mengembangkan industri militer melalui kluster teknologi di Bangalore dan sekitarnya, ditinjau dari corak, tatanan maupun regulasi dalam koridor domain negara sebagai antisipasi internalisasi modal asing dalam pembangunan domestik akan diuraikan lebih lanjut dalam artikel ini.

Kebaruan artikel ini terletak pada deskripsi tentang industri militer, kluster teknologi dan developmental state theory (DST). Agar mampu menciptakan profitabilitas, maka industri militer harus dikembangkan dalam suatu kluster berteknologi tinggi dan memperhatikan berbagai ketentuan yang tercakup dalam teori tersebut mengenai domain negara.

Implementasi domain negara di India terbukti mampu mempertahankan keberadaan DPSU sebagai salah satu instrumen pengendali negara dalam industri militer.

Melalui DST, kluster teknologi mampu digunakan 
sebagai wahana pembangunan guna menjawab permasalahan sektoral khususnya atas pertahanan dan teknologi informasi, karena ventura teknologi yang diproduksinya memberikan kekuasaan guna menjalankan diplomasi ekonomi. Beberapa penelitian terdahulu telah mengeksplorasinya tetapi dengan cara yang terpisah-pisah, sementara secara umum lembah silikon identik dengan kapitalisme dan neo liberalisme, tetapi melalui diplomasi ekonomi, DST mampu memberdayakan kebijakan di balik pengembangan industri militer mereka.

Antara DST, techno park, dan negara berkembang memiliki benang merah terkait dengan karakteristik teori tersebut. Secara umum, terdapat tiga elemen krusial, state, strategy dan market. State menghasilkan konsep state domain, market - dalam hal ini diwakili oleh jaringan/networking, transaksi, investor, dan MNC/Perusahaan Multinasional, sedangkan strategi direpresentasikan oleh regulasi, penguatan kelembagaan, penciptaan agen politik (political agencies) dan diplomasi.

Konsep pertama menunjukkan letak perbedaan India dari dua model klasik dalam DST. Tiongkok berciri khas fully intervention dan Korea Selatan justru sebaliknya, mengambil sikap minimized intervention. Negara ini memiliki corak half intervention, disamping menjalankan kolaborasi dengan pasar, tetap memperluas strategi yang memberikan kesempatan seluas-luasnya bagi firma domestik, baik level entitas global maupun UKM. Karakteristik ini juga berdampak pada spesifikasi strategi Pemerintah India terhadap pasar. Kecenderungan sikap kolaboratif terhadap pasar, sebagaimana dimiliki oleh Tiongkok dan Korea Selatan tetap dipertahankan, namun pemerintah negara tersebut lebih mengutamakan unsur penguatan melalui standar kompetensi bagi firma domestik, penciptaan jaringan yang mendukung peningkatan political agencies bagi kaum diaspora di luar negeri dan diplomasi sebagai pendukung regulasi.

\section{KERANGKA PEMIKIRAN}

Perkembangan aliran developmental paska Perang Dunia II dijelaskan oleh Berberoglu (1992) terbagi ke dalam dua kelompok yakni:

a) Structuralist developmental State, lebih bertumpu kepada peran negara dalam kebijakan industrialisasi, dua opsinya adalah EOI (Export Oriented Industry) atau ISI (Import Substitution Industry). India, Afrika Selatan, Korea Selatan serta beberapa negara Asia Tenggara seperti Singapura adalah contoh negara yang mengaplikasikan berbagai konsep dari tipe ini ke dalam kebijakannya.

b) Capitalist developmental State, membahas peran dan urgensi dominasi negara atas pasar sehingga menciptakan suatu akumulasi modal dalam negara sebagai suatu lembaga yang memiliki kekuasaan sekaligus kedaulatan. Akumulasi modal oleh negara ini menimbulkan suatu regim baru dari kelompok NIC (Newly Industrial Country). Contoh negara yang tergolong kelompok ini adalah Jepang, Tiongkok, dan Taiwan.

Kelompok pertama mengupas berbagai kebijakan dan strategi negara, termasuk melakukan subsidi terhadap infant industry (industri kecil menengah) sehingga mampu meningkatkan ekspor barang/jasa sebagai langkah awal menuju negara industri. Hubungan jangka panjang yang stabil antara state dan industri merupakan kunci bagi penciptaan pola khusus pembangunan dan kemampuan negara dalam melaksanakan pembangunan industri.

Kelompok kedua, menurut Chalmers Johnson (Önio, 1991) berciri khas pembentukan suatu international governed market bagi industri domestiknya melalui pola kelembagaan regional berdasarkan pertumbuhan ekonomi, produktivitas, dan kompetisi dengan dominasi kepemimpinan tunggal negara tersebut. Baik Jepang, Tiongkok bahkan Taiwan masing-masing saling berkompetisi guna meraih kedudukan sebagai pemimpin negara berkembang. Mereka menjadi model state-led development di Asia Timur, dengan karakteristik yang berbeda-beda.

Model Jepang, menurut Johnson (1995) merupakan kelanjutan dari kerangka flying geese, yang sudah dikembangkan oleh Akamatsu pada tahun 1935 ketika menjadi penasehat Kaisar Meiji. Tiga landasannya yang berfungsi sebagai agen pembangunan 
adalah birokrat maupun teknokrat dari unsur pemerintah, keiretzu (jaringan antar MNC), dan diplomasi ekonomi untuk menciptakan suatu jaringan work station di berbagai negara Asia. Embedded autonomy state hanya ditunjukkan melalui dominasi kaum birokrat/teknokrat secara kelembagaan melalui MITI (Ministry of International Trade and Industry) yang menginisiasikan diplomasi ekonomi melalui ODA (Official Development Assistance) untuk merintis terbentuknya jaringan dengan negara tetangga yang terletak dalam jangkauan kekuasaan regionalnya.

Meskipun Tiongkok/Taiwan dan Jepang menunjukkan dua model yang berbeda, namun merujuk pada penelitian Robert Wade (1990) dan Seung (2005) mereka berada dalam jalur capitalist developmental state. Keberadaan Korea Selatan dengan tiga penyangga ekonomi domestiknya, negara, bank dan chaebol, menimbulkan suatu dilema apakah tergolong ke dalam salah satu kategori ataukah terlepas dari keduanya sehingga membentuk kategori tersendiri. Konflik yang muncul adalah jika diklasifikasikan tipe pertama, karena spesifikasi blanket ISI (Patibandla, 2000) lebih mewarnai corak kebijakannya, namun kontribusi dari Hyundai, LG dan Samsung sebagai chaebol justru mendekati tipe yang berbeda. Chin (2006) bahkan mengungkapkan bahwa negara ini sedang bertransformasi menuju model Jepang/ Tiongkok.

Sementara, Pirie (2008) justru dalam artikelnya mengungkapkan peningkatan keterlibatan kaum chaebol, khususnya di masa Lee Myung Bak cenderung membawa mereka menuju neoliberalisme. Meskipun demikian, manajemen Pemerintah Korea Selatan terhadap chaebol dalam pengembangan kluster industri militer di Daejeon kembali memperkokoh bukti bahwa mereka tetap berada dalam koridor teori ini.

Dinamisasi langkah kebijakan Korea Selatan sampai Pemerintahan Park Geun Hye diargumentasikan penulis masih dalam ranah kerangka teori ini dengan mengambil pijakan Minns (2001), otonomi negara terimplikasikan melalui kebijakan dan otoritas finansial, melalui bank sentral serta pengelolaan asset dengan pemberdayaan KAMCO (Korea Asset Manage- ment Corporation). Peneliti lainnya, Mah (2011) memperkuat melalui dalih efektifitas birokrasi dan kaum teknokrat di negara ini, sehingga mampu memberikan corak dan menjaga kelangsungan agar mereka tetap konsisten dengan pola developmentalist.

Penulis mencatat rekam jejak kebijakan India dalam koridor teori ini melalui beragam hasil penelitian yang dilakukan para ahli ekonomi politik, antara lain Bagchi (2003). Menurutnya posisi India adalah sebuah negara dengan demokrasi liberal namun status kebijakan ekonominya justru tidak bersifat neoliberal, karena dominasi peran pemerintah senantiasa melekat, mengendalikan kontribusi swasta dan modal asing. Istilah yang diberikannya adalah embedding a developmental, diversified democracy in developmental state.

Kebijakan industri militer yang dijalankan oleh negara dunia ketiga dilatarbelakangi berbagai motif politis, ekonomis maupun prestise. Ditinjau dari developmental state theory, interaksi dari ketiga aktor menghasilkan posisi tawar menawar antara pemerintah sebagai aktor yang memiliki kekuasaan politik, legislatif selaku pemegang hak ratifikasi dengan $\mathrm{MNC}$ pertahanan sebagai aktor swasta internasional pemegang kekuasaan ekonomi, dalam urusan pengelolaan aset publik.

India dikelompokkan sebagai developmental democratic state. Sebagai negara demokrasi yang sedang mengalami transisi di dalam kebijakannya yang bercorak developmentalist state, berbeda dengan Tiongkok atau Korea Selatan. Tiongkok merupakan developmentalist state murni dengan single majority bertumpu pada Partai Komunis Cina, sedangkan Korea Selatan adalah democratic developmental states, karena mampu menyeimbangkan dua konsep yang berbeda, antara demokrasi dan pembangunan. Hasil penelitian para ahli ekonomi politik seperti, Martinussen (2001), Sinha (2003), mengargumentasikan kebijakan ekonomi politik India berbeda dengan Tiongkok atau Korea Selatan.

Martinussen (2001) mendeskripsikan salah satu ciri khas kebijakan India setelah tahun 1991 adalah menempatkan pemerintah dalam posisi seimbang antara modal asing dengan swasta domestik. 
Implementasinya dijalankan melalui kebijakan fiskal dan non fiskal, termasuk di dalamnya regulasi status ratna bagi DPSU/Defense Public Sector Undertaking dan Raksha Udyog Ratna (RUR) menjadi ambang batas investasi bagi firma domestik. Sementara Sinha (2003) kembali menegaskan, keberadaan model India ini terlihat dari harmonisasi hubungan antara pemerintah pusat dengan negara bagian. Segala regulasi terkait dengan pemberdayaan sumber daya alam maupun manusia, menjadi kewenangan negara bagian.

Klausul ini kemudian memberikan peluang bagi negara bagian guna mengembangkan beragam techno park. Ketika terjadi inisiasi kebutuhan inkubasi maupun katalisasi dalam suatu techno park sehingga mampu berkembang menjadi kluster industri militer, maka pemerintah federal mengambil alih peran ini, serta menjalankan langkah start up.

Kebijakan fiskal, sebagai salah satu unsur strategi dalam model ini, menurut Nayar (2010), mutlak dijalani karena globalisasi dan liberalisasi merupakan dua fenomena dalam satu kesatuan "ekonomi dan sosial", dan negara sebagai penjaga dampak negatif dari keduanya dituntut menjalankan disiplin fiskal, di bawah kendali pemerintah federal/fiscal federalism. Pengetatan disiplin fiskal ini harus dijalankan menyeluruh atas segenap sektor pembangunan. Kelangsungannya menuntut kepatuhan dari segenap aktor pemangku kepentingan sektoral.

Kebijakan fiskal dan non fiskal menurut Low (2004), merupakan bagian dari strategi pemerintah dalam DST, khususnya kategori penciptaan suatu lingkungan bisnis yang kondusif. Dua kebijakan tersebut menjadi bagian di dalamnya selain memelihara tatanan politik, menciptakan dan memelihara tatanan hukum antara properti swasta dan hubungannya dengan pasar, penyediaan infrastruktur, serta meminimaliasi terjadinya kekurangan sumber daya alam dan manusia. Elemen yang terakhir ini menjadi bagian yang cukup krusial dalam implementasi DST di berbagai negara berkembang baik Tiongkok, Korea Selatan maupun India, khususnya dalam pengembangan industri militer.

Dari ketiga pendapat ahli tentang India meneliti industri militer sebagai salah satu sub sektor prioritas pembangunan dengan rujukan DST, menghasilkan tuntunan penelahan lebih lanjut atas beragam prasyarat yang melekat sehingga suatu negara disebut berada dalam koridor teori ini:

a. Eksplorasi keberadaan domain negara (state domain).

b. Deskripsi strategi terpilih, mencakup regulasi, penguatan, penciptaan dukungan politik/political agencies dan diplomasi.

c. Identifikasi kelayakan kondisi pasar sehingga memberikan peluang bekerjanya dua segmen DST seperti tertuang pada poin a dan $b$.

Keberadaan techno park, dalam hal ini kluster industri militer, disebut sebagai variabel terpengaruh (dependent variable). Secara teoritik peneliti mengindentifikasi korelasinya dengan strategi, domain negara serta kondisi pasar selaku variabel bebas (independent variable).

Techno park dan DST bersifat saling melengkapi satu dengan lainnya. Keduanya mutlak dibutuhkan negara berkembang ketika meletakkan sub sektor ini sebagai salah satu prioritas pembangunan. Tanpa penerapan kerangka konseptual teori ini, khususnya sebagai wahana political agent dalam konteks strategi, maka techno park yang dikembangkan serupa dengan wahana sejenis di negara industri. Selain itu tatanannya berfungsi sebagai penjamin kelangsungan inovasi.

\section{HASIL DAN PEMBAHASAN}

DOMAIN NEGARA DAN INTENSITAS AKTOR INDUSTRI MILITER INDIA

Istilah state domain dalam DST telah digunakan oleh beberapa peneliti teori ini, Önio (1991) memakainya untuk memaknai langkah intervensi, keterlibatan pemerintah. Sementara Bolesta (2007) memilih menggunakan istilah intervensi negara, baik fully, minimized maupun half intervention. Doner (2005) mulai menggunakan istilah ini dengan argumen negara tidak hanya menjalankan intervensi saja melainkan juga pelembagaan dalam strategi terhadap pasar.

Kajian industri militer dari sudut DST lebih ditujukan guna eksplorasi teori tersebut ke dalam beragam sektor ekonomi maupun sub sektor ekonomi 
maupun sub sektor industri dengan memperhatikan berbagai ketentuan yang telah disepakati sebagai koridornya. Merujuk kerangka teori di atas, ambang batas keberadaan domain negara adalah,

a. Embedded autonomy of state, tercermin melalui dominasi perusahaan negara (State owned Enterprises/ SoE), kebijakan fiskal, non fiskal dan diplomasi ekonomi atau militer, dan perencanaan pembangunan.

b. Keberadaan birokrat, teknokrat sebagai think tank. Kelompok ini mempelopori perencanaan pembangunan sebagai suatu strategi atas pasar.

c. Terdapat konsensus di antara elit politik, meskipun kondisi politik domestik negara tersebut bersifat multi partai.

Meskipun memiliki latar belakang multi partai, namun pertumbuhan konglomerasi di India cenderung secara langsung mendukung partai yang berkuasa, intensitas lobinya di parlemen juga terbatas. Domain negara lebih ditentukan oleh bargaining position dalam tubuh legislatif, bukan hasil lobby kaum pengusaha. Wujud nyata domain negara type India adalah peranannya sebagai manajer sekaligus penyeimbang antara swasta domestik dengan modal asing - dalam hal ini kontraktor pertahanan.

Bentuk domain ini kemudian menentukan karakter birokrat/teknokrat maupun RUR/swasta domestik yang bersifat netral dan otonom dari politik praktis khususnya aktivitas partai politik. DPSU sebagai perusahaan militer milik negara dan lembaga riset sebagai inkubator juga mengikuti sifat ini. Di sisi lainnya konglomerasi yang dihasilkan jauh berbeda dengan Tiongkok atau Korea Selatan. Di Negara pertama, mereka adalah bagian dari partai penguasa, sementara di negara kedua, mereka secara aktif terlibat dalam persaingan antar partai, bahkan pada suatu masa mampu menjadi penentu kebijakan partai penguasa.

Karena sejak kemerdekaan, landasan kebijakan ekonomi India bersifat lebih menekankan pembangunan industri domestik, maka terbentuklah jenis dan fungsi domain yang bersifat half intervention, sehingga terjadi keseimbangan peran antara pemerintah, swasta domestik dan perusahaan multinasional. Dalam industri militer, DRDO/Defence Research and Development Organization sebagai lembaga riset pemerintah yang didirikan pada tahun 1958 mengkoordinir jaringan pusat penelitian dan laboratorium militer. Karena perkembangannya cukup pesat maka beberapa tahun kemudian, 1962 didirikan Department of Defense Production sebagai lembaga produksi yang membawahi delapan DPSU dan 41 Ordnance Factories/OF (Gupta, 2012).

Keterlibatan industri militer domestik di India memiliki fungsi ganda bagi pemerintah maupun MNC pertahanan. Bagi pemerintah, partisipasi aktif firma domestik sebagai sub kontraktor dari SoE militer selain memberikan peluang efisiensi anggaran belanja militer, juga menjadi wahana transfer teknologi. Sementara bagi MNC pertahanan, pemberian kewenangan bagi firma domestik India untuk menjalin kerjasama dengan mereka, menjadi jalan untuk merintis privatisasi industri militer di negara berkembang melalui kerja sama ventura antara swasta baik domestik maupun internasional.

\section{STATUS RATNA DAN RUR SEBAGAI INSTRUMEN DST}

Pilihan posisi peran pemerintah sebagai manajer, fasilitator dan pemersatu bagi seluruh kelompok kepentingan, juga berdampak dalam struktur kepemilikan saham SoE bidang militer, keterlibatan lembaga departemen maupun otonom sebagai unsur penunjang. Regulasi fundamental atas DPSU dan OF dijalankan melalui konsep hibah status ratna sedangkan bagi firma domestik diberlakukan RUR.

Pemberian status ratna bagi DPSU merupakan hak otonomi, terkait dengan kedudukannya sebagai badan usaha milik negara. Tujuannya adalah memberikan kewenangan khususnya dalam kebijakan investasi, penjualan emisi saham baru melalui pasar bebas. Peringkat maharatna memberikan keleluasaan investasi. Kerja sama produksi, ventura serta penjualan saham dalam jumlah yang lebih besar, nominalnya sampai 5000 crore sementara kewenangan navratna hanya terbatas sampai 1000 crore. Mini ratna memiliki batasan lebih rendah lagi, 300-500 crore atau separuh dari laba bersih (The Times of India, 25 Desember 
2009).

Di antara kesembilan perusahaan, sampai tahun 2016, baru HAL (Hindustan Aeronautics Ltd.) dan BEL (Bharat Electronics Ltd.) yang telah berstatus navratna, sedangkan keenam perusahaan lainnya masih berstatus mini ratna kategori 1. Satu-satunya DPSU yang belum mampu meraih status ratna adalah HSL (Hindustan Shipyard Ltd). Perusahaan ini terbebani produksi kapal selam bertenaga nuklir serta kualifikasi sistem penjaminan mutu, ISO 9001 sebagai suatu perusahaan perkapalan modern sehingga menderita defisit sejak tahun 2013 sampai 2016 (The Times of India, 24 Desember 2009).

Tiga belas perusahaan multinasional India berkategori RUR terlahir dari rekomendasi Kelkar Committee dengan tujuan peningkatan kompetensi swasta sebagai rekanan DPSU maupun jaringan pertahanan internasional. Vijay Kelkar dalam rekomendasinya mengungkapkan tingginya persaingan dalam inovasi persenjataan semakin memperberat DPSU dalam usaha peningkatan statusnya menuju maharatna. Pemberian kewenangan yang lebih besar kepada beberapa entitas global milik bangsa India menjadi salah satu alternatif antisipasi (Sharma, The Hindu, 08 Agustus 2008).

Proses penetapan statusnya memerlukan waktu sampai empat tahun, karena Kementrian Pertahanan India (MOD) membutuhkan konsultasi serta pertimbangan yang cukup mendalam dengan CII (Confederation of Indian Industry) dan Federation of Indian Chambers of Commerce and Industry (FICCI). Tahun 2007 terbentuk komite seleksi tingkat tinggi (Sengupta Committee) atas RUR. Komite ini menetapkan batasan kualifikasi RUR sepadan dengan status navratna. Nilai kontrak minimum bagi mereka sebagai rekanan DPSU maupun kontraktor pertahanan adalah Rs 1000 crore bagi jalur kendaraan baja dan Rs 5000 crore untuk pesawat dan kelautan (Behera, 2008).

Hibah status ratna dan RUR berdampak pada kecenderungan interaksi kelompok kepentingan (domestik) dengan jaringan kontraktor pertahanan dan karakteristik bisnis militer. Tidak semua entitas swasta global India berkonsentrasi serta memiliki divisi berjalur produksi barang/jasa militer. RUR sebagai representasi swasta global memiliki karakteristik serta peran krusial yang sebanding dengan chaebol di Korea Selatan. Sebagai bagian dari birokrat, Kelkar Committee telah membuka jalan ke arah desinvestasi, namun permasalahan utama terletak pada fungsi khusus DPSU/OF dalam anggaran defisit adalah sebagai wahana pemenuhan kebutuhan Angkatan Bersenjata India, agar tingkat ketergantungan terhadap persenjataan impor maupun investasi asing bisa berkurang. Beban ini berdampak pada pajak tidak langsung atas produksinya. Penetapan kuantitas atas pajak tidak langsung yang cukup tinggi bagi DPSU justru akan membebani pemerintah sendiri sebagai pembeli utama. Para pembuat kebijakan lainnya berkehendak mempertahankan perimbangan andil dari pemangku industri militer (Behera, 2013).

Sebagai jalan tengah, kriteria hibah status ratna merupakan rujukan penjaminan mutu secara menyeluruh mulai dari peluang kenaikan harga saham, sampai dengan prediksi disinvestasi dan potensi pasar produksi barang maupun jasa perusahaan. Nominal ambang batas yang telah ditetapkan terhadap PSU maupun firma domestik telah dipertimbangkan para pembuat kebijakan sehingga isu disinvestasi bukan menjadi sebuah fenomena yang terlarang namun justru diantisipasi dengan tuntutan kualitas serta kompetensinya guna bersaing dalam pasar global (Kelkar, Inclusion, Januari - Maret 2010).

Kriteria setiap ratna bagi setiap DPSU menjadi pembatasan secara kuantitatif terhadap kompetensi mereka melalui instrumen fiskal di atas. Komitmen pemerintah dalam mengkontrol kualitas produksi barang maupun jasa yang dihasilkan secara langsung tercermin dari konsistensinya untuk mengikuti setiap tahapan perkembangan mereka serta berusaha mengendalikannya melalui instrumen fiskal tersebut. Sebagai pemegang saham utama, pemerintah bisa melakukan percepatan menuju status navratna dengan prediksi emisi saham dalam pasar modal harus mampu menaikkan ketiga segmen utama (Koner, 2014).

Kompetensi RUR menempatkan mereka sebagai peringkat pertama ketika pelelangan beragam proyek 
pemerintah maupun kerja sama dengan modal asing, sesuai dengan ketentuan DPP. Beberapa perusahaan multinasional milik Bangsa India yang belum mampu mencapai status tersebut tetap didorong serta diberikan kesempatan menjalankan bisnis jasa militer melalui sistem BPO - outsourcing. Masa ROI (tingkat pengembalian investasi) bagi industri militer cukup lama, apabila jumlah aktiva lancar yang dimiliki belum cukup besar sesuai dengan kuantitas RUR, maka perusahaan tersebut akan memiliki masalah finansial di awal pengerjaan suatu tender persenjataan (Behera, 2008).

Ketentuan RUR secara fiskal merupakan standar penjaminan mutu bagi perusahaan yang berinisiasi memperbesar atau merintis jalur produksi militer. Prediksi Vijay Kelkar atas sistem Public Private Patnership ini (jagranjosh.com, 29 Desember 2015) dalam jangka panjang akan mampu meringankan beban pembelanjaan militer negara, sekaligus memperkuat posisi mereka sebagai salah satu tiang penyangga industri militer nasional. Kebijakan ini juga memberikan ciri khas bagi India, khususnya penguatan swasta domestik yang sebanding dengan usaha peningkatan kapasitas perusahaan negara guna menciptakan situasi kondusif bagi kontraktor pertahanan maupun modal asing sebagai katalisator sub sektor industri ini (Singh, 2010). Tata Group, misalnya telah memiliki jangkauan bisnis militer mulai dari pesawat, peluru kendali, arm drone sampai dengan kelistrikan dan jasa konsultansi militer. Begitu pula dengan Mahindra \& Mahindra Ltd., entitas global ini bahkan mampu memperluas jalur produksi militernya, tidak hanya dalam senjata altileri, namun sampai pada pemprosesan baja dan jasa militer, khususnya bagi penerbangan (Behera, 2013).

Sebagian saham Larsen \& Toubro dipegang pemerintah sehingga secara langsung perusahaan ini berkonsentrasi sebagai sub kontraktor DRDO, ISRO serta DPSU bidang Kelautan dalam mengembangkan persenjataan modern seperti rudal balistik, landasan peluncuran roket, dan kapal selam bertenaga nuklir. Meskipun secara kuantitas kontribusinya terbatas, namun mampu mengurangi tingkat kerugian Goa
Shipyard Ltd., Mazagon Dock Ltd., Garden Reach Shipbuilders $\mathcal{E}$ Engineers Ltd. dan Hindustan Shipyard Ltd. sebagai perusahan militer negara bidang perkapalan (Chhibber, 2013).

Peran sebagai rekanan pemerintah dalam industi militer juga dikembangkan Godrej. Melalui Precision Division Ltd. Divisi militer ini memiliki dua anak perusahaan dalam bisnis militer, Godrej and Boyce Ltd. dan Godrej Aerospace Ltd.. Yang pertama berkonsentrasi guna inisiasi kerja sama ventura atau produksi, khususnya dengan kontraktor pertahanan atau PMSC. Salah satu hasilnya adalah Efacec Engenharia dari Portugis untuk pembuatan robot dan pesawat nir awak. Sedangkan yang terakhir lebih ditujukan sebagai fasilitasi sub kontraktor, baik domestik maupun asing (firstpost.com, 14 Agustus 2014).

Kirloskar Ltd. merupakan perusahaan alat berat ternama India dengan keunggulan dalam pompa dan generator. Perusahaan ini menjadi pintu masuk Toyota, dalam usaha perluasan jaringan investasi otomotifnya di India. Pasca 2008, Divisi "Kirloskar Brother Ltd." (KBL) ditugaskan menginisiasikan bisnis militer, khususnya sebagai penyedia peralatan serta suku cadang pesawat, landasan peluncuran roket atau rudal balistik. Dukungan Toyota memberikan dampak global bagi perusahaan ini. Sampai tahun 2014, perusahaan ini telah menjadi sub kontraktor pembuatan dry dock, port trust dan infrastruktur perkapalan lainnya bagi Angkatan Laut India. Melalui konsep "Fluid Management System", KBL berhasil menjadi penyalur beragam jenis pompa modern seperti concrete volute, BHM T130 bagi kepentingan proyek pembangkit energi nuklir atau kelistrikan baik domestik maupun PMSC. Kapasitasnya sebagai RUR mampu mengimbangi Tata Power Ltd.. Bisnis internasionalnya per tahun 2013 telah mampu menyumbangkan 30\% dari penghasilan perusahaan (Atarodi, 2010).

Hinduja Group sebagai Holding Company dari Ashok Leyland, memiliki strategi pengembangan tersendiri. Sebagai entitas global yang telah mencapai peringkat RUR, divisi ekspor perusahaan kemudian 
bergabung dengan dua entitas global terkemuka dalam konsultasi dan manajemen, Capgemini Ltd. (Perancis) dan Frost \& Sullivan Ltd. (AS). Melalui keduanya maka perusahaan bisa memasarkan berbagai produksi persenjataan dan jasa konsultasinya ke berbagai belahan dunia, khususnya Asia Pasifik dan Afrika. Perusahaan lainnya dalam kelompok konsorsium ini, yakni Hinduja Technology Ltd. melengkapi fasilitas penawaran produksi maupun jasa Ashok Leyland Defense System sehingga prediksi satu dasawarsa ke depan, perusahaan tidak hanya terkonsentrasi pada sistem persenjataan bagi angkatan darat maupun para militer saja, melainkan juga penerbangan dan C4ISR (capgemini.com, 13 Nov 2014).

Kalyani Group bahkan berkembang cukup pesat setelah Bharat Forge menerima status RUR (showdailys.com, 7 Feb 2014). Perkembangan empat belas anak perusahaannya mampu mendukung kompetensinya sebagai entitas global bidang infrastruktur dan forging. Keragaman divisinya cukup lengkap mulai dari jasa konsultan, penyalur bahan mentah baja sampai penyedia beragam suku cadang yang sangat dibutuhkan berbagai sub sektor industri. Bharat Forge sebagai ujung tombak, memiliki manajemen tersendiri, di bawah kendali BF Investment Ltd.. Di samping itu Hikal Ltd. menjamin kelangsungan inovasi beragam produksinya melalui beragam riset. Sejak tahun 2014 telah dilakukan kerja sama ventura dengan Elbit Systems sebagai perusahaan senapan terkemuka milik pemerintah Israel (kalyanigroup.com, 19 September 2015).

Tiga perusahaan multinasional India berkualifikasi RUR yang tersisa adalah Infosys Technologies Ltd., Wipro Technologies Ltd. dan HCL Technologies Ltd.. Ketiganya bergerak dalam bidang computer dan IT. Meskipun kontribusinya dalam industri militer bertema sejenis yakni jasa konsultasi IT bagi kepentingan militer/pertahanan, C4ISR (Command, Control, Communications, Computers, Intelligence, Surveillance and Recognaissance) dan Penerbangan maupun masing-masing memiliki spesifikasi berbeda antara satu dengan lainnya. Infosys lebih menekankan pada dua konsentrasi: kerja sama riset dengan institusi pendidikan asing di satu sisi, sementara di sisi lainnya mengkontrol pengembangan divisi berjalur jasa militernya secara langsung tetap di bawah kendali perusahaan. Sementara Wipro Technology justru sangat menekankan kerja sama ventura/produksi dengan kontraktor pertahanan utama seperti Boeing, Lockheed Martin, Northrop and Grumman, Airbus, dan BAE. Sedangkan HCL Technologies lebih meningkatkan fungsinya sebagai konsultan penerbangan (Chhibber, 2013).

\section{PENGEMBANGAN KLUSTER INDUSTRI MILITER MELALUI TECHNO PARK}

Neumann (1994) mengemukakan bahwa kluster industri berteknologi tinggi di bidang informasi akan mampu memberikan peluang negara Dunia Ketiga untuk mengkomersialisasikan industri militernya karena tingkat pembelanjaan dalam litbang militer dalam kondisi tertentu justru akan menguntungkan sistem ekonomi domestik jika bisnis militer ini dilakukan dengan cara maupun kaidah industri sipil termasuk teknik dan materialnya. Penelitiannya membantah hasil penelitian Degler (1983) atas beberapa LDC (Least Developed Country) termasuk India, bahwa secara kuantitatif, sedikit sekali dampak positif pengeluaran militer terhadap pembangunan, bahkan lebih besar negatifnya karena banyak mengurangi tabungan nasional.

Lebih lanjut lagi dikemukakan Neumann (1995) makna komersialisasi industri militer adalah kemampuan suatu LDC untuk menangkap peluang, sesuai dengan kemampuan serta keunggulan regional yang dimilikinya sehingga tetap mampu menjual produk industri militernya, meskipun dalam wujud jasa. Military support - training, dukungan logistik, informasi intelijen, sebagai salah satu bentuk jasa militer non-combatant yang sarat dengan teknologi tinggi, telah mampu menunjukkan kontribusinya dalam industri militer. Negara penggunanya bisa negara Barat maupun berkembang di sekitarnya yang sedang terlibat konflik. India, sudah lama merintis trainer sebagai bentuk output industri militernya sehingga meskipun ekspor persenjataan mereka relatif kecil, 
namun kerjasamanya dengan Argentina, Brazil, mampu mencatat $80 \%$ produksi sistem persenjataan di negara Dunia Ketiga.

Adam Segal (2004) pun sependapat, AS tidak mungkin menghambat laju perkembangan industri militer di negara kawan maupun rivalnya - baik di Barat maupun LDC. Tuntutan inovasi yang berkesinambungan semakin menyulitkan negara Adi Kuasa tersebut untuk mempertahankan posisinya di tempat teratas apabila tidak melakukan perubahan kebijakan di bidang militer sejak dini. Kendala utama yang dihadapi oleh negara Adi Kuasa tersebut adalah peningkatan kompleksitas dalam keamanan regional tidak memungkinkan lagi sistem monopoli, justru dengan kerjasama internasional akan mampu menciptakan suatu pasar modal yang menguntungkan kedua belah pihak.

Sejalan dengan konsep yang dikemukakan kedua ilmuwan di atas, Bitzinger (2009) berpendapat bahwa negara Dunia Ketiga tetap mampu berkontribusi dalam industri militer global di Abad 21 ini asal berkonsentrasi pada keberadaan RMA yang berbasis teknologi informasi. Lebih lanjut dijelaskan bahwa dampak dari RMA terhadap pengembangan industri militer adalah keberadaan suatu link antara orang, platform, senjata, sensor, dan berbagai keputusan tentang bantuan militer dari negara lain ke dalam suatu jaringan tunggal. Andrew L. Ross (2008) menyebutnya dengan istilah NCW (Network Centric Warfare).

Setelah itu pengembangan kluster industri di dalamnya, termasuk militer, merupakan pengembangan jalur produk dari teknologi informasi sifat RMA sendiri. Menurut peneliti lainnya, Sloan (2000) coraknya telah menuntun kluster industri militer di dalamnya ke arah dua spesifikasi produk, yakni: a) persenjataan dan pesawat tempur dengan ketepatan bidikan terhadap sasaran, meskipun berjarak ratusan mil kilometer (precise strike) dan b) satelit dan chip yang memiliki kemampuan battlespace awareness dalam menjalankan.

Bagi negara berkembang, kluster ini menjadi wahana alih teknologi serta memperoleh dukungan finansial internasional bagi industrinya. Leslie (1996) bahkan mengungkapkan jika beberapa negara berkembang di Asia menggunakan kluster teknologi ini untuk mencapai keunggulan regional. Hanya coraknya berbeda, di sana dominasi pemerintah terlihat menonjol. Leslie menyebutkan dua contoh negara dengan konsep pengembangan lembah silikon yang berbeda. AS di satu sisi mengembangkan dengan liberalisasi dan privatisasi, sedangkan Korea Selatan mengintegrasikannya dengan kebijakan pemerintah, khususnya di bidang pendidikan, riset dan strategi pembangunan.

Breznitz (2007) meneliti pengembangan kluster teknologi di Israel, Taiwan, dan Irlandia. Hasil penelitiannya menegaskan urgensi peran pemerintah dengan alasan untuk menanggulangi kegagalan pasar, karena di satu sisi tuntutan pembiayaan yang cukup tinggi sementara dari segi permintaan tidak mampu memberikan daya beli yang sebanding. Modal ventura, menjadi tidak optimal dalam pengalokasian sumber daya. Selain itu, menurutnya, kebijakan pemerintah merupakan langkah yang cukup krusial karena proses inovasi itu sendiri bersifat kerja kolektif antara pemerintah dan swasta. Sehingga, pemerintah harus secara aktif memfasilitasi link antara industri domestik dengan pasar global baik dengan jaringan produksi maupun finansial.

Kaitan antara DST dengan techno park, terletak pada strategi yang diambil oleh negara model secara khusus dalam kluster ini sebagai antisipasi terhadap pasar. Segmen yang menonjol adalah penguatan, penciptaan political agent dan diplomasi. Penelitian Yun (2002) atas kaum diaspora Tionghoa berkebangsaan Taiwan di AS menunjukkan keberhasilan pemerintah Taipei untuk menarik kaum diaspora Cina sehingga bersedia kembali ke tanah airnya, merupakan ancaman bagi neoliberalisme. Min Ye (2009) bahkan mengemukakan, keberadaan jaringan diaspora Tionghoa yang kuat dengan pemerintah lokal di PRC melalui mekanisme difusi, mampu mendorong Pemerintah Beijing sehingga semakin kolaboratif terhadap pasar, dan berdampak pada pembentukan zona ekonomi khusus serta desakan reformasi terhadap 
kebijakan atas SoE.

Dalam kaitan antara diplomasi dengan penciptaan political agent melalui techno park sebagai instrumen insentif, sehingga terjadi suatu ikatan, kepedulian sampai dengan partisipasi terhadap pembangunan domestik tanah air mereka, Rana (2014) membandingkan usaha diplomasi antara India dengan Tiongkok dalam kerangka peningkatan political agent dari kaum diaspora masing-masing. Tiongkok dipandang lebih berhasil karena didukung oleh beragam konsorsium bisnis Cina serta kaum profesional, sedangkan India mengalami kendala minimnya fasilitasi pemerintah terhadap keinginan, aspirasi kaum diaspora India.

\section{KEBIJAKAN FISKAL DAN NON FISKAL SEBAGAI CIRI KHAS INDIA DALAM DST}

Sebagai strategi terhadap pasar, kedua kebijakan, baik fiskal maupun non fiskal, secara sederhana mampu memberikan sebuah tatanan fundamental bagi negara ini sehingga secara kontekstual tetap berada di jalur DST sehingga Mukherji (2016) menyebut India sebagai model non klasik, karena corak dua kebijakan ini. Posisi industri militer sebagai salah satu sub sektor prioritas India, membuat dua kebijakan ini terlihat nyata perbedaannya dengan Tiongkok dan Korea Selatan sebagai dua model klasik.

DPP (Defense Procurement Procedure) sebagai kebijakan fiskal khusus bagi industri militer memiliki komposisi perimbangan yang lebih longgar bagi modal asing dalam segmen tertentu, namun tetap memberikan ruang gerak bagi perusahaan negara dan firma domestik - entitas global maupun industri berskala kecil dan menengah. Sementara kreasi dalam SEZ (Specific Economic Zone) meskipun tidak mencakup klausul subsidi gaji pegawai berkebangsaan India yang bekerja pada modal asing seperti dua negara sebelumnya, namun tetap mampu menjadikan zona tersebut sebagai lokasi pasar tenaga kerja internasional.

Kedua kebijakan di atas, merupakan hasil andil yang seimbang diantara pembuat kebijakan India, dimotori oleh kaum birokrat. Aspek rasionalitas lebih didahulukan daripada kepentingan parsial. Hal ini terlihat nyata dalam dinamika DPP sampai tahun 2013, khususnya pada perubahan komposisi kerja sama ventura/produksi pada setiap konsep - buy, make, buy and make serta segmen - low technology mature system, high technology complex system dan strategic, complex and security sentive system. Wacana yang tersirat adalah sikap terbuka yang lebih luas terhadap modal asing/jaringan kontraktor pertahanan namun tetap menjaga dampak negatifnya dengan tuntutan pelaksanaan alih teknologi melalui konsep buy and make diiringi dengan tuntutan internal bagi modal manusia dengan konsep make.

Dua jenis kebijakan moneternya - devaluasi dan holding/sekuritas, saling melengkapi sehingga negara ini terbebas dari dampak negatif penurunan nilai rupee atas US \$ oleh RBI (Reserve Bank of India). Konsorsium yang telah dibentuk RUR memiliki konsep sekuritas dan ruang gerak luas dan fleksibel, khususnya pasar modal di Eropa. Ketika ekonomi domestik sedang terpuruk akibat krisis moneter maupun dampak devaluasi, kondisi industri militer tidak terpengaruh karena ketersediaan pasar bagi jalur produksi jasa militer tetap stabil, karena terjamin oleh keberadaan pangsa pasar tradisional maupun potensial. Sektor jasa secara umum tahan terhadap krisis moneter. Selain itu konsorsium milik RUR memiliki sekuritas berbasis pasar modal Eropa, padahal devaluasi dilakukan atas US \$, sehingga berbagai valas Eropa yang bersifat hard currency, cenderung menstabilkan likuiditas perusahaan mereka.

Tata Sons sebagai konsorsium milik Tata group menempatkan bisnis militer sebagai salah satu prioritas utama mereka. Konsorsium ini bahkan pernah mengakuisisi saham Daewoo ketika mengalami kebangkrutan dan dijual di pasar modal Eropa. Beberapa tahun kemudian seluruh saham miliknya dijual kepada KAMCO (Korea Asset Management Corporation) yang kemudian dialihkan pada POSCO (Pohang Iron and Steel Company). Kontribusi yang serupa juga diberikan tiga konsorsium swasta lainnya, Hinduja Group, Godrej and Boyce Mfg Co Ltd. dan Kalyani Investment Company Ltd.. Keempatnya menjadi pembeda India dengan Tiongkok maupun Korea Selatan. Di kedua negara tersebut tidak terdapat 
konsorsium swasta yang memiliki keterlibatan cukup besar dalam industri militer.

India termasuk negara pendukung IMF dan aktif menggunakan hak SDR setiap dilanda krisis. Melalui sistem anggaran defisit yang sangat ketat, bersama sama dengan Tiongkok, negara ini tercatat berhasil menggunakan fasilitasi kredit lembaga ini untuk mengatasi ketimpangan neraca pembayaran serta krisis moneter tanpa invervensi eksternal dalam penetapan kebijakan anggaran secara langsung. Kedua negara dipandang telah mampu mengantisipasi dampak negatifnya baik melalui kebijakan fiskal maupun moneter.

Tahun 2014, mencatat kinerja perekonomian India mengalami peningkatan GDP cukup tinggi, meskipun usai menuai krisis moneter akibat fluktuasi harga minyak dunia di tahun 2012. Pada tahun tersebut prosentase kenaikan sebesar $7.17 \%$. Prediksi para ekonom, berdasarkan forecast prosentase kenaikan GDP, jika Pemerintah senantiasa konsisten dalam sikapnya terhadap FDI sebagai katalisator pembangunan, maka angka ini akan terus meningkat sampai tahun 2018 sehingga menjadi 7.65\% (Master, 2014).

\section{KESIMPULAN}

DST tumbuh dan berkembang lebih berwujud sebagai suatu tatanan, bukan merupakan teori yang bersifat statis melainkan berkembang sesuai dengan tuntutan dan kebutuhan LDC dalam mengantisipasi langkah progresif modal asing - FDI dan portofolio. Ketika para pakar meneliti beragam masalah yang dihadapi negara berkembang dalam pembangunan, maka DST muncul sebagai salah satu teori rujukan. Pemberian label suatu negara menggunakan DST atau tidak, bukan dilakukan oleh negara, melainkan para pakar melalui beragam dalih. Keberadaan India sebagai model DST, terletak pada dua konsep utamanya yakni domain negara dan strateginya terhadap pasar. Sifat domain negara mengikuti peran pemerintah yakni sebagai pemersatu, fasilitator tunggal sekaligus menjadi menjadi manajer atas berbagai jenis investasi. Sifat half intervention secara melekat dalam tipe domain ini.
Sementara strategi sangat melekat dalam kebijakan fiskal dan non fiskal.

Herring (1999) mengungkapkan, karakter domain negara yang disebutnya dengan istilah embedded particularism, menjadi kunci utama kegagalan negara ini agar tetap berada dalam koridor developmentalist. Negara dipandang lemah dan tidak mampu mengatasi persoalan sosial ekonomi selain karena pemerintah federal New Delhi lemah dibandingkan dengan negara bagian, konflik antar partai politik semakin memperburuk kondisi negara ini.

Sinha (2005) mengkritisi pendapat ini dengan mengungkapkan istilah kegagalan bagi India dalam hal ini karena mereka meninjaunya dari kerangka domain negara bersifat fully intervention, seperti di Jepang, dan di sisi lainnya keberhasilan peningkatan pertumbuhan ekonomi India hanya dipandang sebagai hasil liberalisasi atas pasar. Menurutnya klaim atas kegagalan maupun keberhasilan India merupakan suatu puzzle yang hilang namun para peneliti justru memandang dari sudut pandang lainnya di luar kerangka DST. Sinha (2003) kemudian berusaha mengelaborasikan keberadaan domain negara dalam pemerintahan India melalui wawancara terhadap sejumlah birokrat dan pelaku bisnis tentang pembuat kebijakan negara tersebut. Hasilnya adalah suatu konsep baru di ranah DST, India telah menunjukkan keberadaan half intervention, suatu komposisi seimbang di antara para pembuat kebijakan, dimana di dalamnya mencakup para pelaku bisnis, legislatif, bahkan negara bagian.

Artikel ini menjadi salah satu pendukung konsep yang diletakkan oleh Sinha. Paparan dalam berbagai bab menunjukkan keberadaan unsur utama half intervention ini seperti jajaran birokrasi yang mampu berfungsi sebagai pelopor think tank of development seperti, DRDO, Kelkar Committe, lembaga riset. Dalam beberapa persoalan pembangunan sektoral, supremasi pemikiran mereka di atas pertikaian antar partai di India. Pemerintahan bisa dipegang secara bergantian oleh Congress Party atau BJP (Bharatiya Janata Party) namun pemikiran para birokrat tersebut secara berkesinambungan tetap diimplementasikan. Selain itu dari kalangan pebisnis, kelompok RUR 
maupun non RUR juga kaum diaspora senantiasa mendukung keberlanjutan program yang telah diletakkan landasan oleh lembaga ini.

\section{REFERENSI}

\section{JURNAL}

Bolesta, Andrzej. 2007. "China as Developmentalist State". Montenegrin Journal of Economics No 5 (June).

Chin, Lim Hyun and Jan Jin- Ho. "Between Neoliberalism and Democracy: the Transformation of the Developmental State in South Korea". Development and Society Volume 35 No 1 (June).

Degler, Saadet and Ron Smith. 1983. "Military expenditures and Growth in Less developed Countries. Journal of Conflict Resolution, Vol 27 No 2 (June).

Doner, Richard F (et. al.). 2005. "Systemic Vurnerability and the Origins of Developmental States: Northeast and Southeast Asia in Comparative Perspective". International Organization 59 (Spring)

Gupta, PK. 2012. "General Study of Public Sector Undertakings: Growth of PSUs and How Effectively Financially Managed are our PSUs". Basic, Applied and Social Sciences. Volume ll Oct

Koner, Sri Santosh (et. al.). 2014. "Disinvestment of Public Sector in India: Concept and Different Issues." Journal of Economics and Finance Vol 3 Issue 6 (May - Jun)

Leslie, Suart W and Robert H Kargon. 1996. "Selling Silicon Valley: Frederick Terman" model for Regional Advantage. The Bussines History Review, Vol 70 No 4 (Winter)

Minns, John. 2001. "Of Miracles and Models: the Rise and decline of the Developmental State in South Korea". Third World Quarterly (Vol. 22 No 6)

Min, Ye. 2009 "Policy Learning of Diffusion: How China Opened to Foreign Direct Invesment". Journal of East Asian Studies Vol 9 No 3 (Sept-Dec)

Neuman, Stephanie G. 1984. "International Stratification and Third World Military Industries". International Organization Vol 38 No 1 (Winter)

1994. "Arm Transfers, Military Assistance, and Defense Industries: Socio economic Burden or Opportunity?". Annal of the American Academy of Political and Social Science Vol 535: The Arm Trade: Problem and Prospect in the Post Cold War World (Sept) 1995. "The Arm Trade, Military Assistance and Recent Wars: Change and Continuity". Annal of The American Academy of Political and Social Science, Vol 541: Small Wars (September)

Öni', Ziya. 1991. "The Logic of the Developmental State Asia's Next Giant: South Korea and Late Industrialization by Alice H. Amsden; The Political Economy of the New Asian Industrialism by Frederic $C$. Deyo; MITI and the Japanese Miracle by Chalmers Johnson; Governing the Market: Economic Theory and the Role ofGovernment in East Asian Industrialization by Robert Wade"(Article Review). Comparative Politics, Vol. 24, No. 1 (Oct)

Patibandla (et. al.). 2000. "Import Substitution with Free Trade: Case of India's Software Industry". Economic and Political Weekly Vol 35 No 15 (April)

Rana, Kishan S. 2014. "Diplomacy Systems and Processes: Comparing India and China. China Report 50: 4
Ross, Andrew L. Peter Dombrowski. 2008. "The Revolution in Military Affairs, Transformation and the Defence Industry". Security Challenges, Vol. 4, No. 4 (Summer)

Segal, Adam. 2004. Is America Losing Its Edge? Innovation in a Globalized World. Foreign Affairs. Vol 83 No 6 (Nov-Dec)

Seung, Wook Baek. 2005. "Does China Follow the East Asian Development Model". Journal of Contemporary Asia Vol 35 no 4

Sinha, Aseema. 2003. "Rethinking the Developmental State Model: Divided Leviathan and Subnational Comparisons in India". Comparative Politics Vol 35 No 4 (July)

Sloan, Elinor. 2000. "Canada and the Revolution in Military Affairs: Current Response and Future Opportunities". Canadian Military Journal (Autumn)

\section{BUKU}

Atarodi, Alexander (et. al.). 2010. "India: A defence and Securiry Primer". Monograf of FOI. Stockholm: FOI Press

Bagchi, Amiya Kumar. 2003. The Developmental State in History and in the Twentieth Century. New Delhi: Regency Publications

Baskaran, Angathevar. 2005. "The Role of Offsets in Indian Defense Procurement Policy" dalam Jurgen Brauer, dan J Paul Dunne. 2005. Arm Trade and Economic Development: Theory, Policy and Cases in Arms Trade Offsets. New York: Routlegde.

Behera, Laxman K. 2013. "Indian defence Industry Issues of Self Reliance". IDSA Monograf Series No 21. New Delhi: Institute for Defence Studies and Analyses Press

Berberoglu, Berch. 1992. The Political Economy of Development: Development Theory and The Prospect for Change. New York: State University of New York Press

Bitzinger, Richard A. 2009. The Modern Defense Industry: Political, Economy, Technological Issues. California: ABC-CLIO

Breznitz, Dan. 2007. Innovations and the State: Political Choice and Strategies for Growth in Israel, Taiwan and Ireland. New Haven: Yale University Press.

Chhibber Brajesh (et. al.). 2013. "A bright Future for India's Defense Industry?"Monograf of McKinsey on Goverment. New Delhi: McKinsey Press

Herring, Ronald J. 1999. "Embedded Particularism: India's Failed Developmental State dalam Meredith Woo and Cumings. 1999. The Developmental State. London: Cornel University State Press

Hoyt, Timothy D. 2007. Military Industry and Regional Defense Policy: India, Iraq and Israel. New York: Routlegde

Johnson, Chalmers. 1995. Japan: Who Governs?: The Rise of the developmental State. New York: W.W. Norton Company Inc

Martinussen, John Degnbol. 2001. Policies, Institutions, and Industrial Development: Coping with Liberalisation and International Competition in India. New Delhi: Sage Publications India Pvt Ltd

Leamer, Edward E. 1995. The Heckscher Ohlin Model in Theory and Practice. New Jersey: Pricenton University Press

Low, Linda. 2004. Developmental States: Relevancy, Redundancy, or Reconfiguration. New: York: Nova Science Publishers, Inc

Martinussen, John Degnbol. 2001. Policies, Institutions, and Industrial Development: Coping with Liberalisation and International Competition in India. New Delhi: Sage Publications India Pvt Ltd Mukherji, Rahul. 2016. "Is India a Developmental State" dalam Yin, 
Wah Chu (ed).2016. The Asian Developmental State: Reexaminations and New Departures. London: Palgrave Macmillian

Nayar, Baldev Raj. 2010. Globalization and Politics in India. Oxford: Oxford University Press

Pirie, lain. 2008. The Korean Developmental State: from Dirigisme to Neo-liberalism. New York: Routledge

Sinha, Aseema. 2005. Regional Root of Developmental Politics in India: A Divided Leviathan. Indianapolis: Indiana University Press

Wade, Robert. 1990. Governing the Market: Economic Theory and the role of Government in East Asia Industrialization. New Jersey: Princeton University Press

Yun, Han Chu. 2002. "Re-engineering the Developmentalist State in Age of Globalization: Taiwan in Defiance of Neoliberalism". The China Review Vol 2 No 1 (Spring)

\section{MAKALAH INTERNASIONAL}

Mah, Luis. 2011. "Lesson from Korea to Africa: Leaders, Politics and Developmental States. International paper for $4^{\text {th }}$ European Conference on African Studies $17^{\text {th }}$ June 2011 Uppsala (Swedia) oleh CEsA (Centro de Estudossobre Africa e do Desenvolvimento) lembaga riset dari Insituto Superior de Economia e Gestao da UniversidadeTecnica de Lisboa

Gupta, Poonam and Barry Eichengreen. 2011. "The Service Sector as India's Road to Economic Growth. Working paper that was presented to National Bureau of Economic Research (NBER) on February.

\section{INTERNET}

"Ashok Leyland Enriches Massive Data with Superior BI Capabilities" tersedia dalam https://www.capgemini.com/resource-file- data diakses pada tanggal 19 Januari 2015 pukul 13.30 access/resource/ pdf/ ashok_leyland_enriches_massive_data_with superior bi capabilities.pdf

Behera, Laxman K. 2008. "Private Sector Participation in India Defence Industry" tersedia dalam http://www.idsa.in/taxonomy/term/593 data diakses pada tanggal 19 Januari 2015 pukul 13.30

"Defence may Notify Companies cleared for Raksha Udyog Ratna Status". The HINDU. 8 August 2008 data diakses pada tanggal 19 Januari 2015 pukul 13.30

General Knowledge Today. News. April 2013. "Minimum Support Price Scheme" tersedia dalam http://www.gktoday.in/minimum-supportprices/ data diakses pada tanggal 28 April 2015 pukul 15.30

"How Godrej Helped India in Its Fight for Freedom" tersedia dalam http://www.firstpost.com/india/sponsored-how-godrej-helpedindia-in-its-fight-for-freedom-1663841.html data diakses pada tanggal 28 April 2015 pukul 15.30

"Kalyani Group to Intensify its Focus on defence Business" tersedia dalam http://www.kalyanigroup.com/

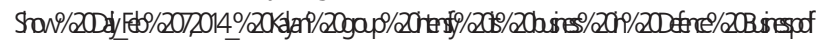
data diakses pada tanggal 28 April 2015 pukul 15.30

Kelkar, Vijay. 2010. "On Strategies for Disinvestment \& Privatisation". Inclusion Jan-March 2010 tersedia dalam http://inclusion.skoch.in/ story/521/on-strategies-for-disinvestment-\&-privatisation821.html data diakses pada tanggal 19 Januari 2015 pukul 13.30

"Kirloskar Brothers Limited- a Kirloskar Group Company 94 $4^{\text {th }}$ Annual
Report 2013 - 2014" tersedia dalam http:// www.moneycontrol.com/bse_annualreports/5002410314.pdf diakses pada tanggal 19 Januari 2015 pukul 13.30

"Maharatna status for mega PSUs gets nod". The Times of India. 25 December 2009. data diakses pada tanggal 23 Feb 2014 pukul 12.14 Wib

Masters, Jonathan. October 2014. The International Monetary FundIntroduction" dalam http://www.imf.org/external/np/fin/tad/ exfin2.aspx?memberkey1 =430\&date1 Key=2015-03-31 data diakses pada tanggal 3 Mei 2015 pukul 06.30

Nune, Shavan. 29 Dec 2015. "Report of Vijay Kelkar Committee on Revisiting \& Revitalizing PPP Model released" tersedia dalam http:// www.jagranjosh.com/current-affairs/report-of-vijay-kelkarcommittee-on-revisiting-revitalizing-ppp-model-released1451371983-1 data diakses pada tanggal 19 Januari 2015 puku 13.30

"On National Security Interest, Govt Moves Hindustan Shipyard to Defence Ministry". The Times of India. 24 December 2009 data diakses pada tanggal 19 Januari 2015 pukul 13.30 